Dept. of Surgery,

Fac. of Vet. Med., Assiut University,

Head of Dept. Prof. Dr. M.H. El-Guindy

\title{
OPEN CASTRATION IN ADULT MALE DOGS: EVALUTION OF NATURAL LIGATURE OF THE SPERMATIC VESSELS (With One Figure)
}

\author{
By \\ F.M. MAKADY; M.A. SELEIM and A.S. SALEH \\ (Received at 4/10/1989)
}

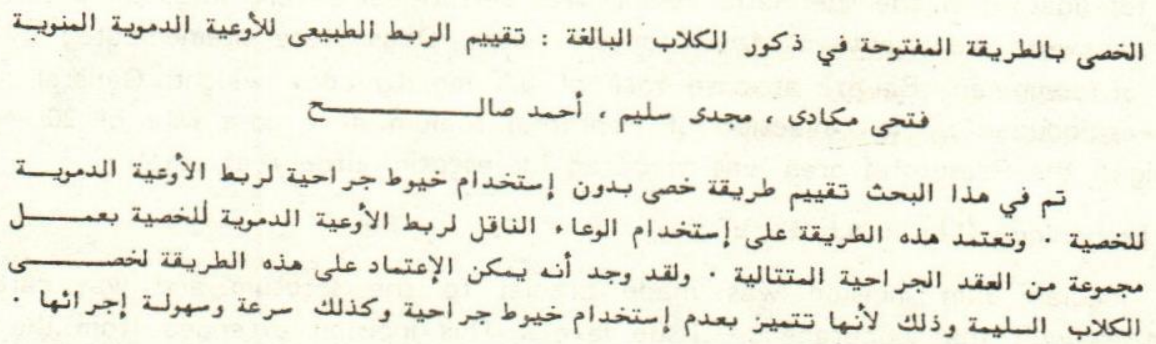

\section{SUMMARY}

A castration technique that does not employ suture material for ligation of the spermatic vessels was evaluated. The technique consisted of making a series of surgeon's knots with the severes vas deferens, in one hand, and the testicular vessels on the other hand. In castration of healthy genitalia, the use of this technique is highly recommended because this procedure have the advantages of using no suture material and of being rapidly performed with practice.

\section{INTRODUCTION}

Castration of male doges is one of the more frequently performed surgical procedures in veterinary practice. ARCHIBALD (1972), BOJRAB (1983) and GOURLEY \& VASSEUR (1985) indicated castration in many diseases of the male genitalia e.g. varicosities of the scrotal vesseis, acute suppurative epididymitis, extensive neoplasms of the scrotum, spermatocele and spermatic granuloma, neoplasms of the epididymis, torsion of the spermatic cord and tumors of the testis. Castration is indicated also to remove objectionable habits of male pets.

There are many techniques of castration, variations of which may involve only the choice of incision site, the method of ligating or knoting the testicular vessels ESTRADA, 1961, ARANEZ \& CRUZ, 1966; MUDALIAR \& REDDY, 1967; ARCHIBALD, 1972; KNECHT, 1976; CELO \& AGUL to, 1978; BOJRAB, 1983 and GOURLEY \& VASEUR, 1985).

Assiut Vet.Med.J. Vol. 23, No. 46, July, 1990. 


\section{F.M. MAKADY et al.}

This study was done to determine the efficacy of a ligatureless technique as an alternative method for crushing and ligation of the testicular vessels in open castration in addult male dogs.

\section{MATERIAL and METHODS}

The study was conducted on 12 clinically healthy mongrel dogs aging 1-5 yearold and weighing $10-15 \mathrm{Kg}$.

In 6 dogs (First group) a castration technique that dose not employ suture material for ligation of the spermatic vessels was performed. Before surgical interference the animals were kept without food for 24 hours. Dogs were premedicated by i.m. injection of combelen (Bayer) at dase rate of $0.5 \mathrm{mg} / \mathrm{Kg}$ body weight. General anaesthesia was induced by i.v. injection of Pentothal sodium at a dose rate of $20 \mathrm{mg} / \mathrm{Kg}$ body weight. the Prescrotal area was prepared for aseptic surgery as usual.

\section{Surgical techanique (Fig. 1 a,b \& c):}

A median Skin incision was made cranial to the scrotum and was carefully extended through the subcutaneous tissue layers. This incision extended from the base of the scrotum a sufficient length cranially to allow expression of each testis through it. The Testis was manipulated toward the incision by digital pressure on the scrotum till protrudes through theskin wound. The tuncia vaginalis is then incised over the testis and was opened longitudinally with scissors to expose the structures of the spermatic cord. The scrotal ligament was transected near its attachement to the testis and the vaginal tunic trimed and excised up to the area of the inguinal ring. The mesorchium was perforated and the vas deferens was clamped with artery forceps andsevered near the epididymis. The testicular vessels were milked in a craniad direction, and were immediately passed over the vas deferens to form the first loop of the surgeons knot with the vas deference in one hand and the testicle still attached to the spermatic cord, on the other hand, traction was applied, the knot made to descend towards the incision until it was approximately near the inguinal canal. The second and third loops were made (reinforced surgeon's knot). The testicular vessels and the vas deferens are clamped with forceps about 1-2 cm. from the knot, and cut to make stump. The stump was held with a thumb forceps and was examined for complete hemostasis. The cord was released under direct thumb forceps control and re-examined for hemostasis. The structure was then allowed to retract into the subcutaneous tissue toward the superficial inguinal ring. The same procedure repeated in theother tecticle.

In 6 dogs (2nd. group), the same technique for castration was performed with one exception is that the spermatic vessels and the vas deferens were ligated by catgut (No. 1) after crushing.

Animals were clinically observed for one month after surgery and postmortum examination was performed to determine any changes at the seat of ligation.

Assiut Vet.Med.J. Vol. 23, No. 46, July, 1990. 


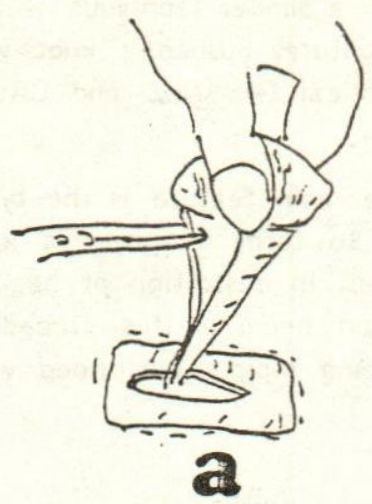

Fig. (1): a- Vas deferns transected.

b- Vas deferns freed from the rest of the spermatic cord.

c- First throw of the surgeons knot.

Testi eular ressels

Vas deferens
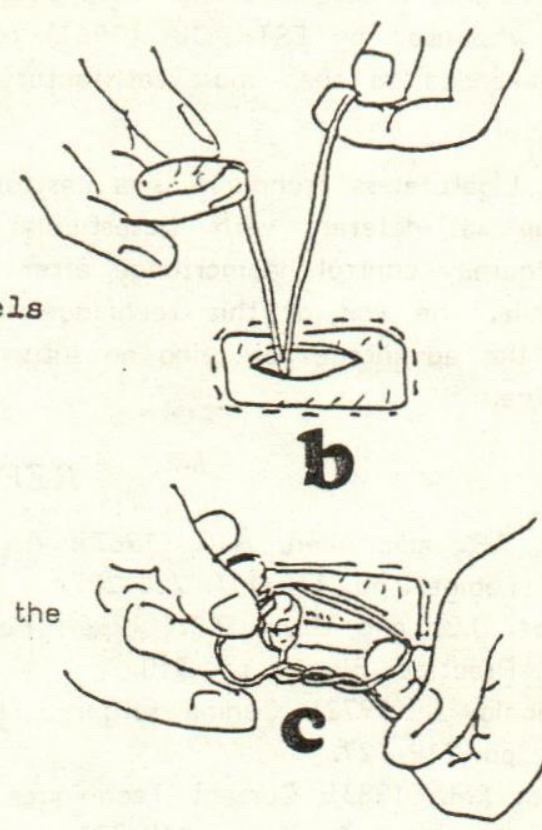

\section{RESULTS}

All dogs withstood the surgical intervention well and manifested no post-operative complications. The skin wounds healed by first intention and sutures were removed on the 8th post-operative day. In the second group, postmortum examination revealed presence of suture material at theseat of ligation with moderate swelling and discoloration of the stump while in the first group the seat of knotting appears as a small stump without any signs of inflammation or haemorrhage.

\section{DISCUSSION}

For castration of dogs there are many incision sites were discused by various authors: scrotal (ARCHIBALD, 1972), inguinal (MUDALIAR and REDDY, 1967), prescrotal (GUARD, 1953; ANNIS \& ALLEN, 1967; BOJRAB, 1983 and GOURLEY \& VASSEUR, 1985) and caudodorsal to the scrotum (KNECHT, 1976). In the present study castration of dogs was performed through a single median incision cranial to the scrotum. The prescrotal incision was chosen because, the thin and sensitive skin of the scrotum is easily irritated by surgical soap and other surgical preparations. The scrotum bleeds heavily and swells post operatively (BOJRAB, 1983), at this site, trauma and contamination are least when the animal is sitting.

Assiut Vet.Med.J. Vol. 23, No. 46, July, 1990. 


\section{F.M. MAKADY et al.}

In the present technique the vas deferens and the testicular arteries and veins are tied into a surgeon's knot to produce natural ligature. In a similar technique square knot was used by ESTRADIA (1961) to produce natural ligature. Surgeon's knot was recommended as then most satisfactory and the most practical (ARANEZ and CRUZ, 1966).

Ligatureless technique is a castration technique whose main feature is the tying of the vas deferens with thetesticular arteries and veins to form a surgeon's knot and thereby control haemorrhage after removal of the testes. In castration of heaithy genitalia, the use of this technique is. highly recommended because this procedure have the advantages of using no suture material and of being rapidly performed with practice.

\section{REFERENCES}

Annis, J.R. and Allen, A.R. (1967): An Atlas of Canine Surgery. Philadelphia: Lea \& Febiger. pp. 132-133: 206-207.

Aranez, J.B. and Cruz, P.S. (1966): Felina orchiectomy techniques, Progress in Feline Practice. Bk. 11, pp. 310.

Aechibald, J. (1972): Canine surgery, 2nd. ed. Wheaton, Illinois: Amer. Vet. Publ., Inc. pp. $719-727$.

Bojrab, J.M. (1983): Current Techniques in Small Animal Surgery, 2nd. ed. Philadelphia. Lea \& Febbbiger. pp. 369-374.

Celo, E.M. and Agulto, A.B. (1978): Sutureless and ligatureless technique of castration in doges and cats, Philippine Journal of Veterinary and Animal Sciences. pp. 42-52.

Estrada, E. (1961): A new castration technic. Mod. Vet. Prac. 42 (14): 42-45.

Gourley, I.M. and Vasseur, P.B. (1985): General Small Animal Surgery. Philadelphia, J.B. Lippincott Company, pp. 690-691.

Guard, W.F. (1953): Surgical Principles and Techniques. Ohio, pp. 182.

Knecht, C.D. (1976): An alternative approach for castration of the dog. VM/SAC, 71: 469.

Mudaliar, A.S.R. and Reddy, R.V. (1967): Castration - New method of ligature. Progress in Canine Practice. Vol. 1, pt.1.pp. 373.QS.

Assiut Vet.Med.J. Vol. 23, No. 46, July, 1990. 